\title{
Nesting ecology of Polistes nimpha (Hymenoptera, Vespidae): a preliminary study in western Poland
}

\author{
Krzysztof Bartosz Kozyra', Edward Baraniak', Marek Kasprowicz² \\ I Department of Systematic Zoology, Faculty of Biology, Adam Mickiewicz University, Umultowska 89, \\ 61-614 Poznań, Poland 2 Department of Plant Ecology and Environmental Protection, Faculty of Biology, \\ Adam Mickiewicz University, Umultowska 89, 61-614 Poznań, Poland
}

Corresponding author: Krzysztof Bartosz_Kozyra (kozyra_k@amu.edu.pl)

Academic editor: J. Neff | Received 13 December 2015 | Accepted 12 June 2016 | Published 29 August 2016

http://zoobank.org/09D7BFF1-1577-4C9B-87F3-2AB829E412CO

Citation: Kozyra KB, Baraniak E, Kasprowicz M (2016) Nesting ecology of Polistes nimpha (Hymenoptera, Vespidae): a preliminary study in western Poland. Journal of Hymenoptera Research 51: 187-201. doi: 10.3897/jhr.51.7508

\begin{abstract}
In 2014 and 2015 we investigated the nesting ecology of Polistes nimpha, one of the paper wasp species common in western Poland. In three selected study plots we collected data about plant species on which P. nimpha foundresses initiate nests, nest height above ground, and nest azimuth. We have observed some preferences of foundresses in relation to these three parameters. Nests are most often initiated on Hypericum, Tanacetum, Daucus and Achillea plants. The preferred range of nest height above ground is 15 to 25 $\mathrm{cm}$, while the preferred nest azimuth is about $110^{\circ}$.
\end{abstract}

\section{Keywords}

Nesting ecology, host plant species, Polistes nimpha, Poland

\section{Introduction}

Most of the available information on nesting sites of the paper wasp Polistes nimpha (Christ, 1791) (Hymenoptera: Vespidae) and its host plant species and nest height above ground is scattered in various publications and usually placed in the description of the study area (Blüthgen 1961, Reed and Vinson 1979, Reeve 1991, Pekkarinen and Gustafsson 1999, Hunt 2007). Differences in nesting site preferences within some 
groups of species of the genus Polistes has been treated as an auxiliary diagnostic feature (Rau 1943).

Polistes nimpha is one of three species of the genus Polistes Latreille, 1802 found in Poland (Oleksa and Wiśniowski 2005). The foundresses usually build nests at a height of 10-20 cm above ground, on various plants, including dwarf shrubs of Calluna vulgaris (L.) Hull, twigs of Rubus spp., thickets of Salix spp., reed beds of Phragmites australis (Cav.) Trin. ex Steud., young Picea sp. (Blüthgen 1961), as well as Achillea millefolium L., Amegdalus nana L., Caragana frutex L., Centaurea jacea L., C. orientalis L., Cirsium ukranicum Bess., Crepis micranhta Czer., Daucus carota L., Hypericum perforatum L., Elytriga elongate (Host) Nevsky, Salvia verticillata L., Tanacetum vulgare L., Silaum alpestre L., Phlomis tuberosa L., Koeleria cristata L., and Panicum capillare L. (Rusina and Bogutskiy 2008, Rusina et al. 2008, Rusina and Orlova 2011). P. nimpha builds an approximately horizontal petiole so that the comb faces to the side. $P$. nimpha is also associated with man-made structures, such as eaves of various buildings (Blüthgen 1961, Cervo and Turillazzi 1985) or attics (Rusina et al. 2007). Nesting at natural or synanthropic sites (man-made structures) may markedly affect how the wasps establish their colonies. In $P$. nimpha, colonies on natural vegetation are usually haplometric (i.e., founded by a single queen), while some of the colonies found on or in buildings are pleometric (i.e., with two or more queens assisting each other) (Cervo and Turillazzi 1985, Rusina et al. 2007).

The available data on the nesting ecology of Polistes nimpha are mostly very brief descriptions of the general vegetation types where the nests were found, although some cited earlier lists of plant species. Only two studies of the paper wasp P. chinensis antennalis Pérez, 1905 from Japan and $P$. nimpha from Ukraine included a list of host plant species and precise numbers of nests on individual plant species (Yamane 1972, Rusina and Bogutskiy 2008).

This study's focus was to determine on which plant species the paper wasps of this species build their nests and to identify the possible preferred features of the plant species during nesting site selection by the foundress. We also took into account the height at which the nest was located and its orientation in relation to the north (azimuth). Additionally, our objective was to verify tentatively whether paper wasp colony survival depends on the plant species on which the nest is located. The collected data allowed us to analyse the nesting ecology by means of determining the wasps' preferences regarding host plant species and nest height above ground and its orientation in relation to the north. This is the first study to analyse the effect of host plant species selection on the survival rate of paper wasp colonies at the pre-emergence phase.

We tested the hypothesis that selection of the plant species on which the nest is located and nest height above ground and its orientation in relation to the north were not accidental, but rather served to maximize the chances of colony survival by improving the thermoregulatory capacity of the wasp nest. The population described in this paper is located at the edge of the general range of this species in Europe, although we know of at least one population of Polistes nimpha located on the Baltic Sea coast (about $250 \mathrm{~km}$ north of Poznań) (Kozyra et al. in press). Nests in both populations were initiated on similar species of plants, and both produced workers, males, and 
queens. From earlier observations we can infer that the climatic conditions for paper wasps in Poland were favourable but not optimal. These ecological characteristics can provide information on how populations of $P$. nimpha act at the edge of its range in Europe (Pekkarinen and Gustafsson 1999) and whether P. nimpha shows the ecological plasticity observed in Polistes biglumis (Yamane and Kawamichi 1975). Furthermore, it can be a potential tool for testing the hypothesis about the selective basis of variation in foundress behaviour and thus clarify the proximate causes of adaptiveness of the natural population organization.

\section{Materials and methods}

We conducted field research in 2014-2015 in three permanent plots located near Suchy Las, at the edges of the military training area in Biedrusko: plot A $\left(52.495892^{\circ} \mathrm{N}\right.$, $\left.16.874196^{\circ} \mathrm{E}, 17,400 \mathrm{~m}^{2}\right)$, plot $\mathrm{B}\left(52.493527^{\circ} \mathrm{N}, 16.873038^{\circ} \mathrm{E}, 5,300 \mathrm{~m}^{2}\right)$, and plot $\mathrm{C}\left(52.495657^{\circ} \mathrm{N}, 16.867265^{\circ} \mathrm{E}, 14,200 \mathrm{~m}^{2}\right)$. We selected these plots because of the favourable conditions for paper wasp nesting (sunny grasslands abandoned for several years), as in similar habitats Polistes nimpha particularly frequents (Szczepko et al. 2009). All the plots were surrounded by spontaneously regenerating wooded habitats. In the immediate vicinity, there were no man-made structures where paper wasps could build their nests.

We started our field research in late April. Initially, we searched for nests along line transects spaced $2 \mathrm{~m}$ apart and marked each nest with a numbered flag. Next, we recorded the host plant species and measured two major parameters of the nests: height at which the nest was located and its orientation in relation to the north (azimuth). We measured nest height as the distance between the ground surface below the nest and its petiole. With a portable magnetic compass, we measured the azimuth as the angle between a line oriented toward the magnetic north and the axis of the wasp nest petiole. We measured (to the nearest $5^{\circ}$ ) the azimuth of each nest three times and took the mean into account. To calculate the geographic azimuth, we added the local magnetic declination (Kryński 2013, 2014) to the measured magnetic azimuth values.

Paper wasp colony survival was studied in 2014 . We controlled the observed nests weekly to determine their condition. We regarded a colony as dead if at least one of the following criteria was met:

- lack of a comb in a place where it was observed before;

- colony destruction (e.g., due to ant predation; without appearance of any new eggs, larvae, and pupae within 2 weeks after predation).

Colony causes of mortality and patterns of changes of Polistes nest numbers are the subject of a separate paper (Kozyra and Baraniak 2016). We did not find a significant impact of temperature on colony mortality; however, some aspects of the impact of weather conditions are described in another paper (Kozyra in prep.). 
We analysed survival rate in the period between the first record of each nest until the first week of June (inclusive). This period spanned nearly the whole pre-emergence phase (i.e., before the appearance of the first worker wasps). We identified wasps' species when we found a nest for the first time or later during measurements or plant identification.

We performed all statistical analyses using GraphPad Prism 5 software. Because the distributions of azimuth and nest height values were not normal, we used nonparametric Kruskal-Wallis and Mann-Whitney tests. We compared the numbers of nests built on different plant species with the chi-squared test.

\section{Results}

During field research in the study area we found 157 nests of $P$. nimpha in 2014 and 127 nests in 2015. In 2014, we assessed nest azimuth and height for 124 nests and plant species for 129 nests, and in another 14 species, identified only the plant family (Poaceae, true grasses). In 2015, we assessed azimuth for 120 nests, height for 127 nests, and plant species for 121 nests.

In total, for both seasons, we found paper wasp nests on 30 plant species (Table 1). Most frequently, the wasps chose Hypericum perforatum, especially in 2014, when we located about $44 \%$ of their nests on the lignified stems of this species, compared to $19 \%$ in 2015. In the first year, paper wasps nested on lignified stems of 16 species, whereas a year later the number of plant species increased to 23 (Table 1). The wasps particularly preferred 6 plant species: Hypericum perforatum, Daucus carota, Tanacetum vulgare, Achillea millefolium, Artemisia vulgaris, and Juncus effusus (Table 1). Out of the 129 nests for which we identified plant species, only 18 survived the pre-emergence phase (Table 2). They were located on the stems of only 4 species: Hypericum perforatum, Daucus carota, Artemisia vulgaris, and Elymus repens.

The geographic orientation of combs was nearly identical and did not differ significantly between the years (Mann-Whitney test, $U=6,899 ; P=0.326$ ) (Fig. 1). For both years the mean azimuth was about $110^{\circ}$, which means that the cell openings in the combs usually faced the east or southeast (Fig. 2). Different nest orientations (i.e., with cell openings facing the west or another direction) were very rare (Fig. 1).

Nest height above ground was similar in both years, although the difference between years was significant (Mann-Whitney test, $U=5,663 ; P=0.0001$ ). The mean height in 2014 was $19.6 \mathrm{~cm}$, whereas it was about $17 \mathrm{~cm}$ in 2015 (Fig. 3).

Nest azimuth on the most frequent plant species was similar in both years (Fig. 4), and the differences were not significant (Kruskal-Wallis test, $H=6.75, P=0.344$ in 2014 and $H=7.095, P=0.312$ in 2015). Nest height above ground was also similar irrespective of the host plant species (Fig. 5). In 2014 it did not differ significantly between plant species (Kruskal-Wallis test, $H=11.8, P=0.086$ ), but in 2015 the differences in this parameter between plant species were significant (Kruskal-Wallis test, $H=16.54, P=0.011)$. The most remarkable difference was observed between Juncus 
Table I. List of plant species on which we found paper wasp nests of Polistes nimpha in 2014-2015.

\begin{tabular}{l|c|c|c}
\hline \multirow{2}{*}{ Plant species } & \multirow{2}{*}{ Family } & \multicolumn{2}{|c}{ Number of nests } \\
\cline { 2 - 4 } & & $\mathbf{2 0 1 4}$ & $\mathbf{2 0 1 5}$ \\
\hline Hypericum perforatum L. & Clussiaceae & 57 & 24 \\
\hline Daucus carota L. & Apiaceae & 20 & 7 \\
\hline Tanacetum vulgare L. & Asteraceae & 5 & 20 \\
\hline Achillea millefolium L. & Asteraceae & 9 & 9 \\
\hline Artemisia vulgaris L. & Asteraceae & 12 & 3 \\
\hline Juncus effusus L. & Juncaceae & 0 & 11 \\
\hline Holcus lanatus L. & Poaceae & 1 & 8 \\
\hline Dactylis glomerata L. & Poaceae & 7 & 2 \\
\hline Rosa canina L. & Rosaceae & 7 & 1 \\
\hline Galium verum L. & Rubiaceae & 0 & 7 \\
\hline Picris hieracioides L. & Asteraceae & 0 & 5 \\
\hline Rumex acetosa L. & Polygonaceae & 0 & 4 \\
\hline Artemisia campestris L. & Asteraceae & 2 & 2 \\
\hline Centaurea stoebe L. & Asteraceae & 0 & 3 \\
\hline Prunus domestica L. ssp. syriaca (Borkh.) Janch. & Rosaceae & 0 & 3 \\
\hline Elymus repens (L.) Gould & Poaceae & 3 & 0 \\
\hline Arrhenatherum elatius (L.) P. Beauv. ex J. Presl \& C. Presl & Poaceae & 0 & 2 \\
\hline Festuca rubra L. & Poaceae & 0 & 2 \\
\hline Poa angustifolia L. & Poaceae & 0 & 2 \\
\hline Pyrus pyraster (L.) Burgsd & Rosaceae & 0 & 2 \\
\hline Agrimonia eupatoria L. & Asteraceae & 0 & 1 \\
\hline Galium album Mill. & Rubiaceae & 0 & 1 \\
\hline Lupinus polyphyllus Lindl. & Fabaceae & 0 & 1 \\
\hline Phleum hubbardii D. Kováts & Poaceae & 0 & 1 \\
\hline Calamagrostis epigejos (L.) Roth. & Poaceae & 1 & 0 \\
\hline Festuca trachyphylla (Hack.) Krajina & Poaceae & 1 & 0 \\
\hline Pinus sylvestris L. & Pinaceae & 1 & 0 \\
\hline Populus sp. & Salicaceae & 1 & 0 \\
\hline Quercus robur L. & Fagaceae & 1 & 0 \\
\hline Senecio jacobaea L. & Asteraceae & 1 & 0 \\
\hline Number of species & & 16 & 23 \\
\hline Total number of nests & & 129 & 121 \\
\hline
\end{tabular}

effusus and Holcus lanatus (Dunn's post hoc test, $p<0.05$ ). Nest height above ground for all nests jointly in 2014 did not differ significantly from the height of the nests that survived the pre-emergence phase (Mann-Whitney test, $U=1,076 ; P=0.54$ ) (Fig. 6).

The plant species composition and numbers of nests on plants of individual species differed between the two years (Fig. 7). The numbers of nests built on the most frequent plant species also differed significantly between years (chi-squared test, $\chi^{2}=$ 53.54, $P<0.0001)$. 


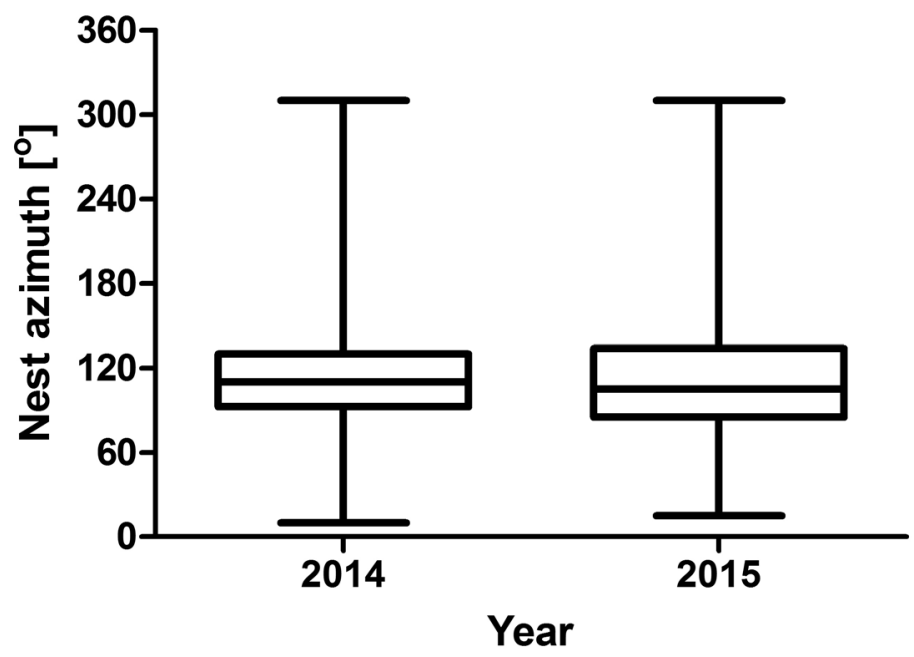

Figure I. Orientation of nests of Polistes nimpha in relation to the north (azimuth) in 2014-2015.

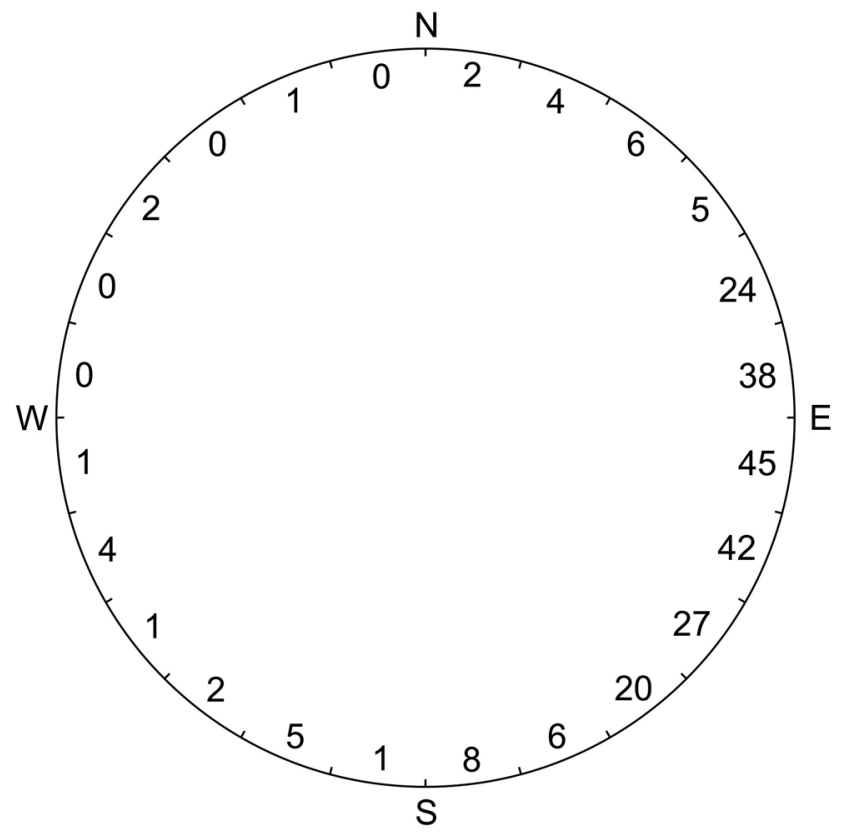

Figure 2. Number of nests with orientation in particular geographic directions in 2014-2015.

\section{Discussion}

The species composition of host plants of Polistes nimpha, especially in the upper part of Table 1, is very similar to that reported by Rusina and Orlova (2011), especially in relation to Achillea millefolium, Hypericum perforatum, and Daucus carota. Foundresses 


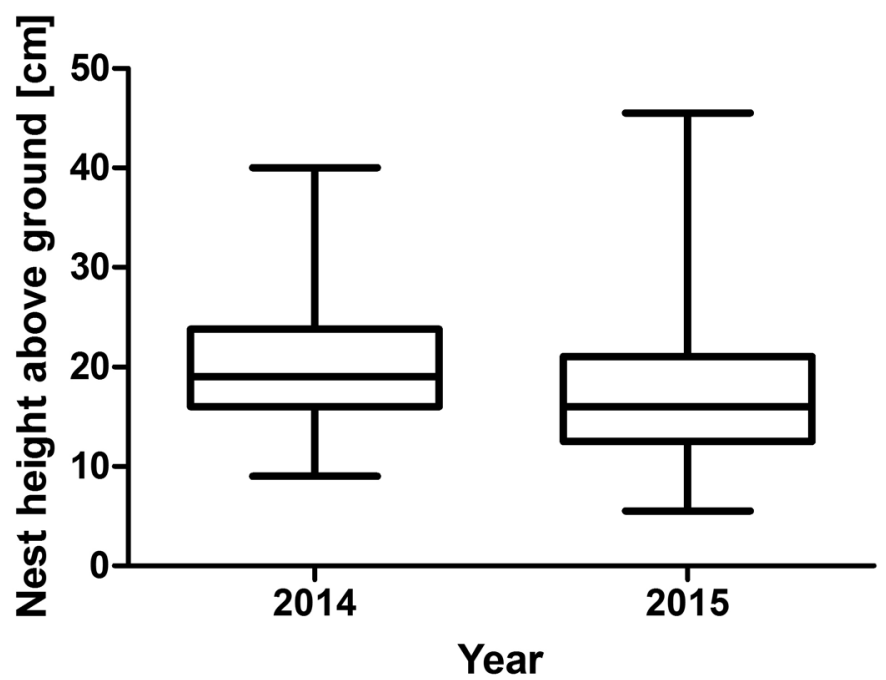

Figure 3. Height at which the nests of Polistes nimpha were built in 2014-2015.

Table 2. Survival rate of colonies of Polistes nimpha, depending on the plant species on which the comb was built in 2014 .

\begin{tabular}{l|c|c|c}
\hline \multirow{2}{*}{ Plant species } & \multicolumn{2}{|c|}{ Number of nests } & \multirow{2}{*}{ Survival [\%] } \\
\cline { 2 - 4 } & Initiated & Survived until worker emergence & 19 \\
\hline Hypericum perforatum & 57 & 11 & 20 \\
\hline Daucus carota & 20 & 4 & 17 \\
\hline Artemisia vulgaris & 12 & 2 & 0 \\
\hline Achillea millefolium & 9 & 0 & 0 \\
\hline Dactylis glomerata & 7 & 0 & 0 \\
\hline Rosa canina & 7 & 0 & 0 \\
\hline Tanacetum vulgare & 5 & 0 & 33 \\
\hline Elymus repens & 3 & 1 & 0 \\
\hline Artemisia campestris & 2 & 0 & 0 \\
\hline Holcus lanatus & 1 & 0 & 0 \\
\hline Calamagrostis epigejos & 1 & 0 & 0 \\
\hline Festuca trachyphylla & 1 & 0 & 0 \\
\hline Pinus sylvestris & 1 & 0 & 0 \\
\hline Populus sp. & 1 & 0 & 0 \\
\hline Quercus robur & 1 & 0 & 14 \\
\hline Senecio jacobaea & 1 & 18 & 0 \\
\hline Total & 129 & 0 & \\
\hline
\end{tabular}

of $P$. nimpha emerge and start to build their nests from April until early May (Kozyra unpubl. data). At that time, the only available nesting sites for wasps in the analysed plots were young trees, shrubs, lignified parts of herbaceous plants, or grass culms 


\section{4}

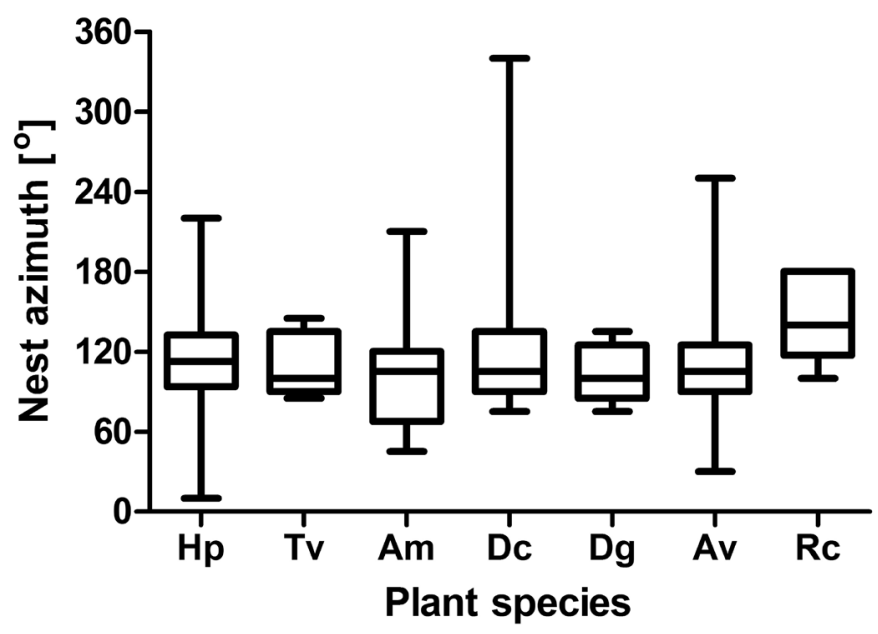

\section{5}

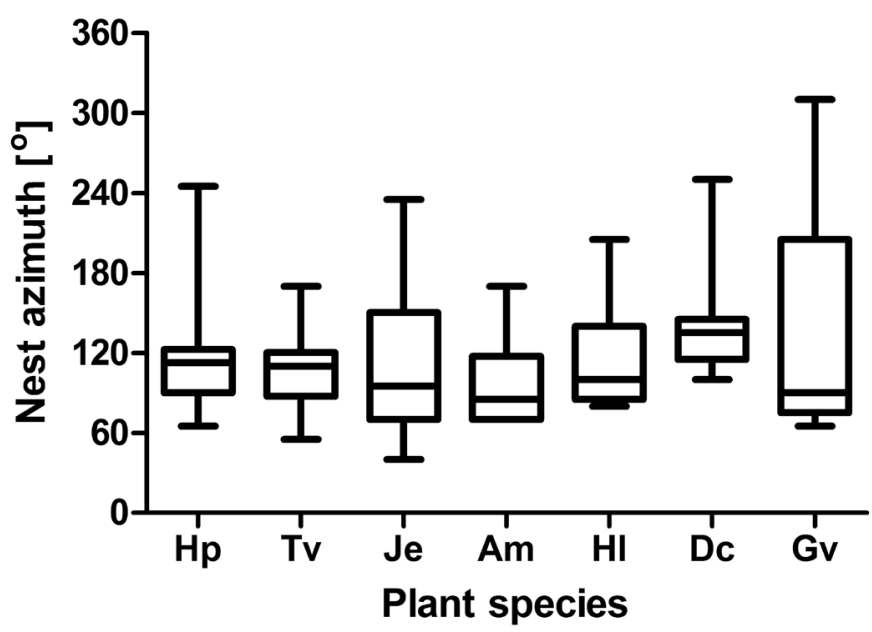

Figure 4. Values of the azimuth of nests of $P$. nimpha, depending on the plant species on which they were built in 2014-2015. Abbreviations: Hp-Hypericum perforatum; Tv-Tanacetum vulgare; AmAchillea millefolium; Je—Juncus effusus; Dc_Daucus carota; Dg—Dactylis glomerata; $\mathrm{Hl}$-Holcus lanatus; Rc-Rosa canina; Gv-Galium verum.

remaining after the winter period. During our study, paper wasps preferred plants characterized by strong, lignified stems (Table 1) that offered them good support.

The wasps also built many nests on culms of various grasses (e.g., Holcus lanatus, Dactylis glomerata, Elymus repens, and Calamagrostis epigejos (Table 1), but grass culms 

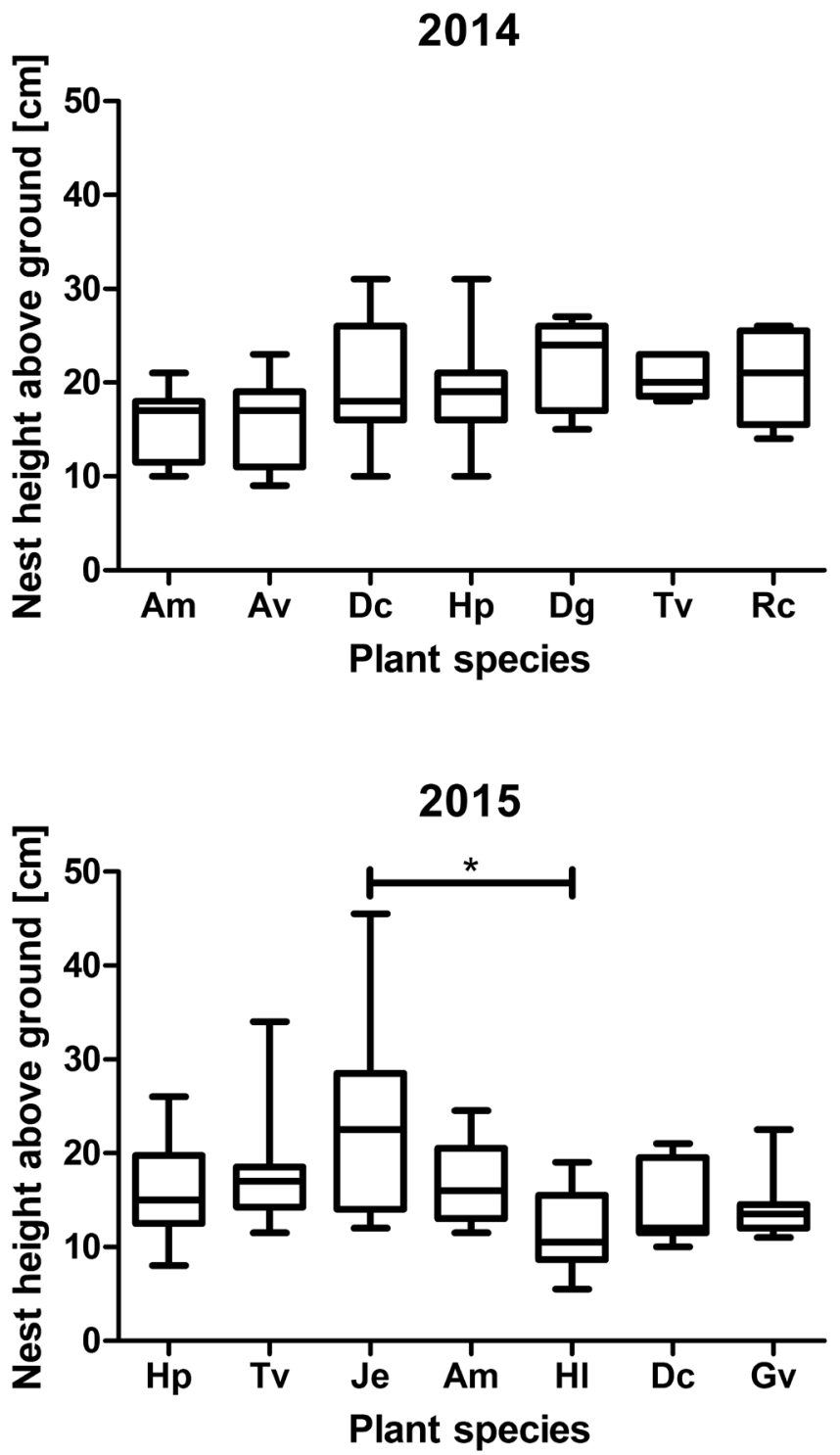

Figure 5. Height at which the nests of $P$. nimpha were built in 2014-2015, depending on plant species. *Dunn's post hoc test, $p<0.05$. Abbreviations: $\mathrm{Hp}-$ Hypericum perforatum; Tv—Tanacetum vulgare; Am-Achillea millefolium; Je—Juncus effusus; Dc_Daucus carota; Dg_Dactylis glomerata; Hl—Holcus lanatus; Rc—Rosa canina; Gv—Galium verum.

are much more delicate than lignified stems of other plants so the nests built on the former are unlikely to survive. In 2014, after the pre-emergence phase, which is the most dangerous phase for colony development, only 1 of the 18 survived colonies was located on a grass (Elymus); the other 17 nests were on plants of the genera Hypericum, 


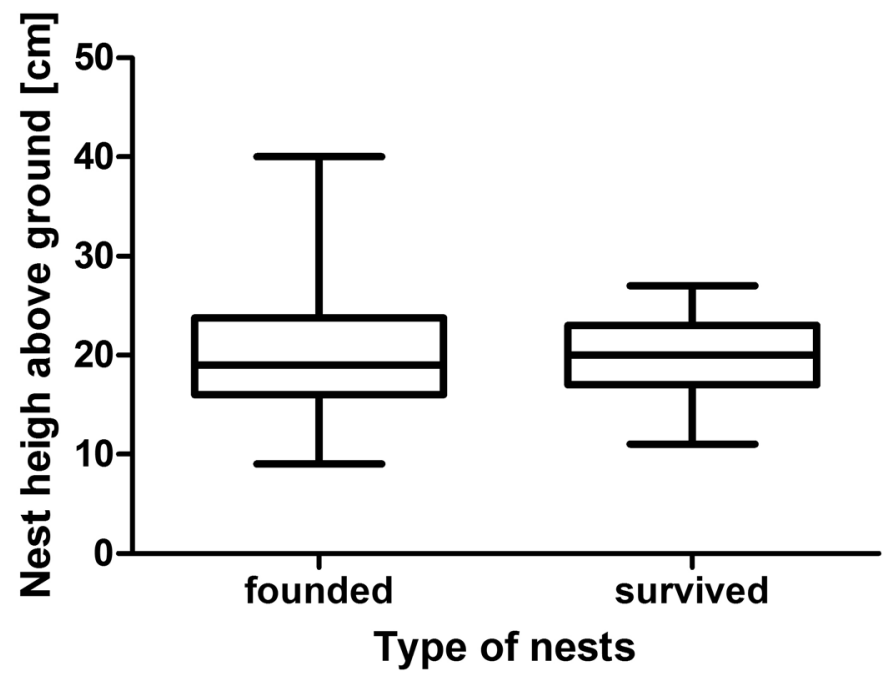

Figure 6. Comparison of the height above ground of all nests founded by Polistes nimpha in the study area with that of the colonies that survived the preemergence phase in 2014.

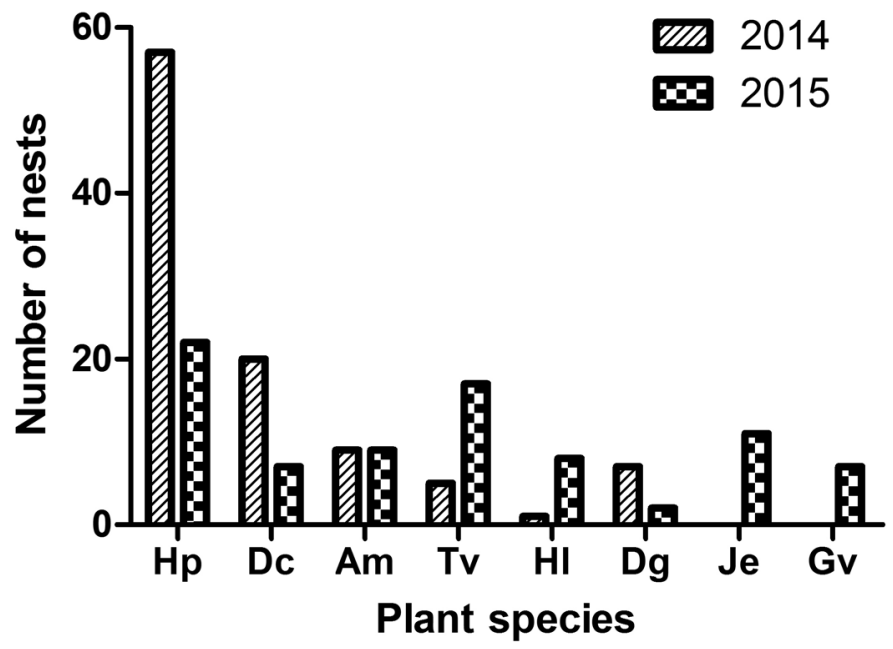

Figure 7. Number of nests of $P$. nimpha built on several most frequent plant species in 2014-2015. Abbreviations: $\mathrm{Hp}$-Hypericum perforatum; $\mathrm{T} \mathrm{v}$ —Tanacetum vulgare; $\mathrm{Am}$-Achillea millefolium; Je—Juncus effusus; Dc_Daucus carota; Dg—Dactylis glomerata; $\mathrm{Hl}$ —Holcus lanatus; Rc—Rosa canina; Gv—Galium verum.

Daucus, and Artemisia (Table 2). Colonies located on shrubs and other grasses did not survive that phase. Nests during their development increased in size and weight. In case of unfavourable weather (e.g., rain, strong winds), weaker substrates such as grass culms are much more exposed to destruction than strongly lignified stems of other herbaceous plants. Ant predation can be another reason for the high mortal- 
ity of colonies, especially of those located on shrubs and young herbs. In contrast to lignified stems of herbaceous plants or the previous year's culms of grasses, the twigs of shrubs and young herbs are living structures, so they are more often penetrated by ants, which search for honeydew, aphids, and other insects. The third, probably major factor is the vegetation located near the nest. If its density is low, the vegetation can be easily penetrated by larger predators, such as wild boars or foxes, which are numerous in the study area. In the analysed plots in 2014, plants of the genera Hypericum, Daucus, Artemisia, or Achillea formed mixed patches. Nesting on plants of this group could reduce the risk of mammal predation and thus increase the chances of colony survival. We never observed foundresses of Polistes nimpha to build their nests in dense patches of grasses; their combs were built mostly in small, isolated clumps. The fourth, undoubtedly significant factor affecting colony survival is nest height above ground. Potential predators can more easily spot nests located high above the ground surface, so this nest location increases the risk of damage to the shoot on which it was built, which leads to colony destruction. Very low nest location can be a problem; most probably it increases the risk of ant predation. The data we collected in 2014 (Fig. 6) show that during the pre-emergence phase, the extreme values were eliminated (the lowest and highest located nests in the observed population declined) and the height of the nests that survived ranged from $15 \mathrm{~cm}$ to $25 \mathrm{~cm}$. The final survival rate of $P$. nimpha colonies was most probably affected by all the above-mentioned factors. Observed mortality during the pre-emergence phase was much higher than in P. biglumis (Linneaus) (Yamane and Kawamichi 1975). Probably it is an effect of stronger activity of predators on study plots near Poznań (Kozyra and Baraniak 2016). Nevertheless the pattern of changes in number of nests during one season still fits the theoretical model of survivorship for paper wasps (Starr 2006).

The pattern of colony mortality during the season we observed in Poland is very similar to results of studies conducted in Italy for Polistes nimpha (Cervo and Turillazzi 1985) and in Japan for P. chinensis antennalis Pérez (Miyano 1980). In both localities mortality during the first phase of the colony cycle was significant but lower than that observed near Poznań. In fact, the number of living nests was certainly a bit higher than that which we observed during our research. In our study we focused only on nests that we located at the beginning of the season. After the nest was destroyed, we did not search for it again to check for possible comb rebuilding. However, in a previous study in the same plots, the researcher had observed some cases in which P. nimpha nests were rebuilt (Kozyra unpublished).

Nest height above ground generally did not differ significantly between host plant species (in 2014, no differences; in 2015, a difference between only Juncus effusus and Holcus lanatus) (Fig. 5), so values of this parameter do not seem to depend on host plant species. For the major plant species in 2014-2015, nest height values fit within the above-mentioned range $(15-25 \mathrm{~cm})$, which confirms the hypothesis that nest height is not accidental. This range of height may protect nests against strong, cold winds at the beginning of the season, at the turn of April and May, especially at high latitudes. On the other hand, foundresses should not build nests too low because 
of further problems with thermoregulation. When daily temperatures increase, the ground accumulates heat and starts to emit thermal energy from the surface. This may cause nests built too low to get not only thermal radiation from the sun but also excessive amounts of thermal energy emitted by the heated ground. The foundress avoids additional costs connected with active nest thermoregulation (fanning and deposition of drops of water in cells) through the choice of proper nest height above the ground (Jones and Oldroyd 2006).

Changes in host plant species composition which may alter the wasps' preferences for some species as nesting sites (Table 1 and Fig. 7) are caused by two major factors. The first factor was the ecological succession of plant communities and the decline of some plant species, which are replaced by others. The second factor was the activity of wild boars in 2014-2015. In plot C, where 94 nests were located in 2015, wild boars were very active. This probably resulted in significant changes in the abundance of individual plant species through the elimination of some patches, which could modify the wasps' preferences regarding host plant selection for nest construction.

The third parameter we analysed was the geographic orientation of the comb. In many social insects, such as ants and termites, the geographic orientation of nests is not accidental and is of great significance for their thermoregulation (for a review, see Jones and Oldroyd 2006). The lack of significant differences in nest azimuth in the population analysed between the years 2014 and 2015 (Fig. 1) and the lack of differences in nest azimuth between the most preferred plant species (Fig. 4) indicate that the foundresses oriented the comb in space in a specific way. Most of the values recorded in both years are within very narrow ranges (Fig. 1), oscillating around $110^{\circ}$. Thus, the cell openings in the combs nearly always face east or southeast, so this orientation does not seem to be accidental. The nests of Polistes nimpha built under the eaves of buildings were usually located on the southern side of buildings (Blüthgen 1961, Cervo and Turillazzi 1985). Yamane (1969) reported that a vast majority of the paper wasps that he studied (i.e., P. snelleni [de Saussure, 1862] and P. biglumis) nested on southern and southeastern slopes. The observed orientation of nests of $P$. nimpha is probably linked with passive mechanisms of nest thermoregulation: probably, if the cell openings face the east or southeast, in the pre-emergence phase of colony development the cells with developing offspring are heated more quickly in the morning by the energy from the rising sun. In early spring, the vegetation around the nests starts to develop, and only after some time they are shaded by the growing plants. Longer periods of high temperature in the nest are a factor enabling faster development of paper wasp larvae (Jeanne and Morgan 1992). This is crucial for the wasps because most of the colonies die during the pre-emergence phase, when there is only one queen (or, rarely, several queens) in the nest, so the defensive potential of the colony is very limited (Miyano 1980, Cervo and Turillazzi 1985, Kozyra et al. 2015).

Yamane and Kawamichi (1975) conducted similar studies for Polistes biglumis at the northern edge of its range in Japan. P. nimpha and P. biglumis are closely related species and, as expected, we observed some similarities between these two species. The life cycles of both species are similar. P. nimpha in Poland, similar to P. biglumis, 
initiates nests at the turn of April and May, and its colonies disappear in September. Furthermore, colonies of both species at the northern limit of their ranges produce full generations of both workers and sexual individuals. A more detailed comparison of life cycles of these two species is forthcoming in a separate paper (Kozyra in prep.).

In conclusion, this study shows that foundresses of $P$. nimpha demonstrate specific preferences for nesting sites regarding their host plant species, nest height above ground, and geographic orientation (azimuth) of the combs. The first 2 factors are important to maximize the chances of colony survival in preemergence phase, the most dangerous, initial part of the colony life cycle, while azimuth most likely functions as a passive mechanism of nest thermoregulation at an early stage of its development, when the surrounding vegetation is still low and allows direct access of sunlight to the comb. Although the nests were built on plants of more than 10 species (Table 2), the vast majority were located on only three species that offer them the greatest chances of colony survival. We made similar observations for nest height: while the range of variation is wide, only the middle part is optimal for colony survival (Fig. 6). Most probably, only the best-adapted foundresses are able to build their nests on a suitable plant species and at an appropriate height, maximizing the chances of colony survival and perpetuating the pattern of preferences in successive generations.

Both height above ground and azimuth seem to play important roles in the passive thermoregulation of paper wasp colonies. In some Polistes species spectacular adaptations to cold climates have been found, such as life cycle plasticity (Yamane and Kawamichi 1975) or a special nest construction called a functional envelope (Yamane 1972). It is very likely that the observed preferences in nest azimuth in $P$. nimpha play a role similar to that of the functional envelope in Polistes species from the northern part of Japan.

\section{Acknowledgements}

We would like to express special thanks for reviewers Lidya Rusina and Christopher K. Starr and editor Jack Neff for valuable comments on the manuscript and great help during processing of the manuscript.

\section{References}

Blüthgen P (1961) Die Faltenwespen Mitteleuropas (Hymenoptera, Diploptera). Abh. Deutsch. Akad. Wiss., Kl. Chem. Geol. und Biol. 2: 1-251.

Cervo R, Turillazzi S (1985) Associative Foundation and Nesting Sites in Polistes nimpha. Naturwissenschaften 72: 48-49. doi: 10.1007/BF00405334

Hunt JH (2007) The Evolution of Social Wasps. Oxford University Press, New York, 280 pp. doi: 10.1093/acprof:oso/9780195307979.001.0001

Jones JC, Oldroyd BP (2006) Nest Thermoregulation in Social Insects. Advances in Insect Physiology 33: 153-191. doi: 10.1016/S0065-2806(06)33003-2 
Jeanne RL, Morgan RC (1992) The influence of temperature on nest site choice and reproductive strategy in a temperate zone Polistes wasps. Ecological Entomology 17: 135-141. doi: 10.1111/j.1365-2311.1992.tb01170.x

Kozyra KB, Melosik I, Baraniak E (2015) Genetic diversity and population structure of Polistes nimpha based on DNA microsatellite markers. Insectes Sociaux 62: 423-432. doi: 10.1007/s00040-015-0421-7

Kozyra KB, Baraniak E (2016) Causes of mortality of Polistes nimpha colonies. Insectes Sociaux 63: 481-482. doi: 10.1007/s00040-016-0484-0

Kozyra KB (in prep.) Phenology of the paper wasp Polistes nimpha (Hymenoptera: Vespidae) and its parasitoid Latibulus argiolus (Hymenoptera: Ichneumonidae).

Kozyra KB, Tyczewska MJ, Eichert UM (in press) New localities of paper wasps Polistes nimpha (Christ, 1791) and Polistes dominula (Christ, 1791) in Poland. Wiadomości entomologiczne. Kryński J (2013) Rocznik Astronomiczny na Rok 2014. Instytut Geodezji i Kartografii, Warszawa. [In Polish]

Kryński J (2014) Rocznik Astronomiczny na Rok 2015. Instytut Geodezji i Kartografii, Warszawa. [In Polish]

Miyano S (1980) Life tables of colonies and workers in paper wasp, Polistes chinensis antennalis, in Central Japan (Hymenoptera: Vespidae). Researches on Population Ecology 22: 69-88. doi: 10.1007/BF02513536

Oleksa A, Wiśniowski B (2005) The paper wasp Polistes dominulus (Christ, 1791) — is it really a critically endangered species in Poland (Hymenoptera: Vespidae: Polistinae)? Wiadomości Entomologiczne 23: 179-188. [In Polish]

Pekkarinen A, Gustafsson B (1999) The Polistes species in northern Europe (Hymenoptera: Vespidae). Entomologica Fennica 10: 191-197.

Rau P (1943) The nesting habits of Polistes wasps as a factor in taxonomy. Annals of the Entomological Society of America 35: 335-338. doi: 10.1093/aesa/35.3.335

Reed HC, Vinson SB (1979) Nesting Ecology of Paper Wasps (Polistes) in a Texas Urban Area (Hymenoptera: Vespidae). Journal of the Kansas Entomological Society 52: 673-689.

Reeve HK (1991) Polistes. In: Ross KG, Matthews RW (Eds) The Social Biology of Wasps. Cornell University Press, Ithaca, New York, 99-148.

Rusina LYu, Rusin IYu, Starr CK, Fateryga AB, Firman LA (2007) Modes of Colony Foundation by Females of Different Morphotypes in the Paper Wasps (Hymenoptera, Vespidae, Polistes Latr.). Enomological Review 87(9): 1155-1173. doi: 10.1134/S0013873807090060

Rusina LYu, Bogutskiy MP (2008) Polistes wasps in Lugansk nature reserve. In: Sova TV (Ed.) Scientific works of Lugansk nature reserve. Flora and Fauna and their conservation. Lugansk, 164-177. [In Russian]

Rusina LYu, Bogutskii MP, Gilev AV, Orlova ES (2008) Phenotypic Structure of Colonies of the Paper Wasp Polistes nimphus (Christ) (Hymenoptera: Vespidae) in the Lugansk Nature Reserve. Kharkov Entomological Society Gazette 15(1-2): 121-130. [In Russian]

Rusina LYu, Orlova ES (2011) The Relationship between Phenotypic Variability in Future Foundresses of Polistes nimpha (Christ) (Hymenoptera, Vespidae, Polistinae) and Infestation of Their Larvae by the Mite Sphexicozela connivens Mahunka (Acari, Astigmata, Winterschmidtiidae). Entomological Review 91(6): 685-691. doi: 10.1134/S0013873811060017 
Starr CK (2006) Steps toward a general theory of the colony cycle in social insects. In: Kipyatkov VE (Ed.) Life Cycles in Social Insects: Behaviour, Ecology and Evolution. St. Petersburg University Press, St. Petersburg, 20 pp.

Szczepko K, Wiśniowski B, Żyła W (2009) Aculeata (Hymenoptera) of Kampinos National Park Part V. Wasps (Vespidae). Wiadomości Entomologiczne 28: 247-270. [In Polish] Yamane S (1969) Preliminary Observations on the Life History of Two Polistine Wasps, Polistes snelleni and P. biglumis in Sapporo, Northern Japan. Journal of the Faculty of Science, Hokkaido University. Series 6, Zoology 17: 78-105.

Yamane S (1972) Life Cycle and Nest Architecture of Polistes Wasps in the Okushiri Island, Northern Japan (Hymenoptera, Vespidae). Journal of the Faculty of Science, Hokkaido University. Series 6, Zoology 18: 440-459.

Yamane S, Kawamichi T (1975) Bionomic Comparison of Polistes biglumis (Hymenoptera, Vespidae) at Two Different Localities in Hokkaido, Northern Japan, with Reference to its probable Adaptation to Cold Climate. Kontyû 43(2): 214-232. 